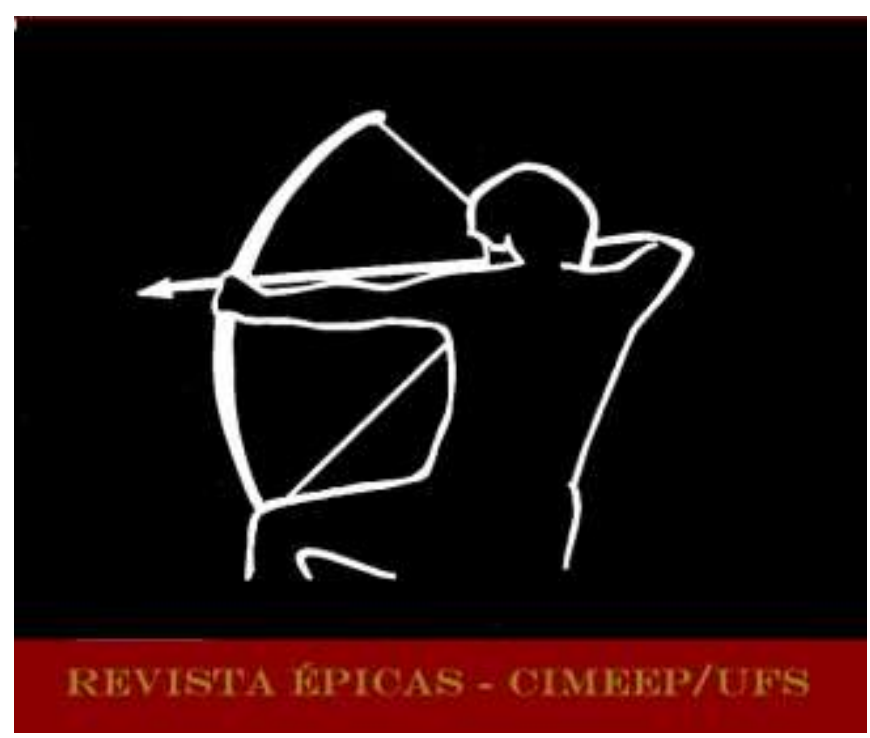

ALVES, Victor Hugo Sampaio. A Kalevala finlandesa: contexto histórico, seu processo de coleta e escrita, questões de gênero e possíveis motivos mitológicos. In: Revista Épicas. Ano 4, N. 8, Dez 2020, p. 226-256. ISSN 2527-080-X.

http://dx.doi.org/10.47044/2527-080X.2020v8.226256

\title{
A KALEVALA FINLANDESA: CONTEXTO HISTÓRICO, SEU PROCESSO DE COLETA E ESCRITA, QUESTÕES DE GÊNERO E POSSÍVEIS MOTIVOS MITOLÓGICOS
}

\section{THE FINNISH KALEVALA: ITS HISTORICAL BACKGROUND, COLLECTION AND WRITING PROCESSES, MATTERS OF GENDER AND PROBABLE MYTHOLOGICAL MOTIFS}

\author{
Victor Hugo Sampaio Alves ${ }^{1}$
} Universidade Federal da Paraíba - UFPB

RESUMO: Escrita no século XIX, a Kalevala é a epopeia do povo finlandês. Seu conteúdo foi embasado em canções tradicionais épicas coletadas por Elias Lönnrot durante onze viagens feitas por territórios da Finlândia e Carélia. 0 objetivo do presente artigo é contextualizar historicamente o surgimento dessa obra em meio ao desejo de emancipação e construção de identidade do povo finlandês, ambos fortemente influenciados pelo movimento do Romantismo. Discutiremos também os processos de coleta, textualização e edição da Kalevala, que vieram a ser influenciados por certos modelos que Lönnrot tinha em mente. Terminaremos por tentar oferecer uma possível categorização de gênero desse material e elencando alguns dos temas nele presentes que estão conectados a tradições mitológicas.

Palavras-chave: Kalevala; Épicos; Finlândia; Mitologia.

ABSTRACT: Written in the $19^{\text {th }}$ century, the Kalevala is held as the epic of the Finnish people. Its content was based in the traditional epic songs collected by Elias Lönnrot during eleven field trips through Finland and Karelia. The goal of the present paper is to present the historical background which gave birth to such a work, knowingly, the Romantism-influenced desire to build a Finnish common identity and to symbolically emancipate the country from foreign rulers. We are also going bring into light the processes of collection, textualization and edition took by Lönnrot during the creation of the Kalevala, as well as the models he had in mind while doing so. Finally, we are going to

1 Mestre e doutorando em Ciências das Religiões, Universidade Federal da Paraíba. Membro do Núcleo de Estudos Vikings e Escandinavos (NEVE) e da Finnish Literature Society (SKS). E-mail: victorweg77@gmail.com 
present a possible categorization of this material in regards to gender, also revealing some of its contents which are connected to mythological themes from the vernacular tradition.

Keywords: Kalevala; Epics; Finland; Mythology.

\section{Introdução}

Símbolo máximo de orgulho² da identidade e cultura finlandesas ainda nos dias de hoje, a Kalevala ${ }^{3}$ é objeto de infindáveis estudos e análises, principalmente entre estudiosos oriundos da Escandinávia e do norte do Báltico. Essa obra literária pode ser abordada de vários ângulos distintos, a depender das perguntas que visamos responder e qual característica dela pretendemos enfatizar, que vão desde o campo da literatura ao dos estudos da religião e da mitologia, passando por estudos de oralidade, textualização, gênero e recepção. São vastas as possibilidades de investigação da Kalevala e as perspectivas e metodologias que podem ser empregadas para tal.

No Brasil, contudo, ainda são muito poucos os que se aventuraram a analisar esse riquíssimo material (e que, inclusive, é parte inegável da grande história mundial da literatura). Nesse sentido, destacamos a dissertação de mestrado e a tese de doutorado de Carolina Alves Magaldi (2006; 2013), que foi pioneira ao eleger a Kalevala como seu objeto de análise em ambos os trabalhos, além de ter se dedicado a esse material também em artigos (2009; 2010). Digno de menção é também o estudo de Marcos Saulo de Assis Nóbrega (2016), em que são analisadas as influências temáticas da Kalevala nas composições do ilustre compositor finlandês Jean Sibelius.

Talvez essa escassez de estudos voltados ao épico finlandês se dê, por um lado, por conta de uma predileção, já consolidada academicamente no Brasil, pelos épicos do mundo clássico

\footnotetext{
2 Exemplo disso é o fato de que, na Finlândia, todo dia 28 de fevereiro é celebrado o Dia da Kalevala.

${ }^{3}$ Notamos que, no Brasil, circulam as duas formas de concordância de gênero frente a esse material (tanto a Kalevala quanto $o$ Kalevala). Apesar de ambas as formas serem possíveis (pode-se fazer a concordância pensando em o épico Kalevala ou a epopeia Kalevala), vislumbramos um novo modo de se pensar essa questão. É necessário chamar a atenção para o fato de que os idiomas fínicos (dentre os quais se encontram não apenas o finlandês, mas também o estoniano, o careliano, o íngrio, o vepsiano e o vótico, e alguns outros mais) não possuem gêneros em sua gramática, não fazendo uso, portanto, de artigos definidos denominadores de gênero, como o ou $a$. Portanto, para trazer alguns dos substantivos finlandeses para o português, ainda que sem traduzi-los, podemos fazer a concordância semântica do gênero: Kalevala é o nome poético conferido, na obra, à Finlândia, cujo significado é algo como "terra dos heróis". Essa questão geográfica é de suma importância ao longo do épico, pois grande parte de sua temática gira justamente em torno dos heróis de Kalevala e seus inimigos da terra de Pohjola. Concordando com a ideia de Kalevala enquanto nome que designa terra e pátria, optamos pelo uso da concordância a Kalevala. O mesmo tipo de procedimento será adotado para outros termos em finlandês que possam surgir ao longo do artigo, que serão devidamente explicados no momento de seu primeiro aparecimento. Essa estratégia semântica para fazer a concordância de gênero, em português, de termos finlandeses, foi saída adotada por nós em tradução de artigo do folclorista finlandês Frog (2019), que sugeriu tal procedimento para as palavras intraduzíveis tietäjä, luonto e väki.
} 
(principalmente A llíada e A Odisséia de Homero, a Teogonia de Hesíodo, a Eneida de Virgílio, embora não limitada a eles), o que não necessariamente constitui um problema, mas acarreta em disparidades. Por outro lado, temos que pensar a falta de acesso à Kalevala aos falantes de português: contamos somente com a tradução de José Bizerril \& Álvaro Faleiros (2015), que apresenta apenas o primeiro grande poema da obra (são nove ao todo), representando parte ínfima desse material finlandês. Uma saída interessante para os não leitores de línguas estrangeiras é recorrer à tradução de Merja de Mattos-Parreira \& Ana Isabel Soares (2013) ao português europeu.

Ainda assim, a Kalevala e os materiais mitológicos e religiosos que a precedem e embasam ainda não foram analisados a fundo por nenhum estudo brasileiro. Tampouco foram delineadas discussões a respeito de seu gênero e processos de textualização que a abarcam, lacunas essas que pretendemos começar a preencher com o presente artigo. Primeiramente, faremos uma breve contextualização histórica e cultural da obra propriamente dita e de seu autor, Elias Lönnrot, apontando também para o processo de coleta dos poemas e as regiões de onde estes são oriundos. Em seguida, partiremos para questões de definição e gênero a respeito da Kalevala, apontando também para problemas de autenticidade e prováveis dificuldades ao tomá-la por fonte completamente fidedigna dos mitos e da religião finlandesa pré-cristã. Por fim, evidenciaremos resquícios, existentes na Kalevala, de temáticas mitológicas advindas da tradição vernacular. Trazer uma discussão densa sobre esses supracitados aspectos da epopeia finlandesa representa não apenas discutirmos mais, em idioma português, materiais épicos outros, fora do

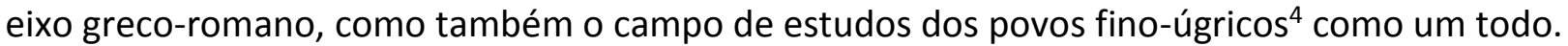

\section{Desenvolvimento}

A Kalevala foi escrita por Elias Lönnrot (1802-1884), médico finlandês que viria a se tornar professor de língua e literatura finlandesa na Universidade de Helsinque. Entre os anos de 1828

\footnotetext{
4 O fino-úgrico é um sub-ramo linguístico dentro do grande grupo das línguas urálicas. O urálico representa a maior família linguística do norte eurasiático e consiste em pelo menos 30 idiomas; o limite geográfico dessas línguas é amplo, indo desde, na parte ocidental, o norte da Noruega e a Hungria e, na parte oriental, a Península de Taimir, juntamente dos rios lenissei e Ob, da Sibéria ocidental. Dentro da família urálica, o sub-ramo fino-úgrico inclui idiomas como o finlandês e demais línguas Balto-Fínicas (estoniano, íngrio, careliano, izoriano, vepsiano, etc.); as línguas sámis, o mari, o mordiviano, o udmurto, o komi, o húngaro, o mansi e o khanty, dentre outras (ABONDOLO, 2006, p. 1-2).
} 
e 1844, Lönnrot fez onze viagens para províncias do norte e do leste finlandês, registrando e coletando uma série de poemas que circulavam em oralidade no meio campesino dessas regiões, unificando-os, posteriormente, em um mesmo corpus que viria a ser conhecido como a Kalevala (HONKO, 1990a, p. 9).

Ao pretendermos analisar o épico finlandês e seus conteúdos, devemos considerá-lo, basicamente, em dois aspectos essenciais - cada um deles capaz de se desdobrar em inúmeras discussões e questionamentos -. Por um lado, ele é produto dos temas e motivos mitológicos que, de alguma forma, ainda circulavam na época em que foram registrados; por outro, ele não deixa de ser produto de uma empreita assumidamente estética e erudita de Lönnrot, carregando, nesse sentido, as marcas e exigências trazidas pelo Período Romântico para que fosse considerada um épico nacional. A Kalevala, portanto, foi concebida acima de tudo enquanto trabalho de história mítica, língua e memória do povo finlandês, cujo alicerce era o conteúdo mitológico coletado pelo autor - ainda que a Kalevala, conforme veremos, possua diversas alterações e empreitas autorais da parte de Lönnrot e não possa ser considerada um retrato completamente fidedigno da mitologia finlandesa -. Talvez devamos considerar Lönnrot não apenas o escritor da epopeia finlandesa, mas um estudioso também pioneiro da mitologia comparada que, na época, incluía nomes como Max Müller e Jacob Grimm (PENTIKÄINEN, 1999, p. 3). A seguir, abordaremos esses e outros aspectos em maiores detalhes.

\subsection{A Kalevala: o contexto histórico-cultural de seu surgimento, suas diferentes versões e o processo de escrita e coleta de materiais por Elias Lönnrot}

Em 1812, sobre forte influência do ideal Romântico, quatro estudantes amigos ${ }^{5}$ juraram dedicar suas vidas à promoção e divulgação da cultura finlandesa, no que se tornou o início de um longo processo histórico que viria a se desenrolar e que buscava uma diferenciação cada vez

\footnotetext{
${ }^{5}$ Carl Gottlund, Adolf Ivar Arwidsson, Abraham Poppius e Anders Johan Sjögren. Adolf Ivar Arwidsson viria a ficar famoso por sua máxima, "Suecos nós não somos, russos não podemos nos tornar, que sejamos, então, finlandeses" (PENTIKÄINEN, 1999, p. 17).
} 
maior entre os finlandeses e suecos ${ }^{6}$, seus dominadores por séculos a fio ${ }^{7}$. Esse juramento foi inspirado pelas ideias do filósofo alemão Johan Gottfried Herder, para quem havia um declínio nas sociedades ocidentais que aderiam a modelos culturais estrangeiros e desvalorizavam línguas e literaturas nativas. Herder convocava uma revitalização das culturas e nações por meio do resgate do folclore, da poesia e das tradições de cada povo, que constituíam, segundo ele, a forma mais verdadeira de expressão do espírito nacional (TOLLEY, 2013, p. 115-116). Todas as nações, de acordo com o autor, se encontravam em processo de progressão em direção a um estado utópico almejado, chamado Humanität, mas cada nação deveria alcançá-lo seguindo a trilha de sua própria cultura, desenvolvendo sua própria linguagem, arte, literatura, religião, costumes e leis $^{8}$ (WILSON, 1976, p. 29).

Contudo, o fervor trazido pelos ideais de Herder, que impulsionou os finlandeses em busca de sua identidade fínica - sobretudo em oposição à sueca - foi ironicamente uma vantagem para que as autoridades russas conquistassem a Finlândia em 1809. Elas se aproveitaram desse movimento para estimular o rompimento cultural e identitário definitivo entre os finlandeses e o estado sueco, que já se perdurava havia séculos. Nesse ano a Finlândia, então, livra-se do domínio sueco para tornar-se um Grão-Ducado autônomo do Império Russo. Tal fato ilustra bem como, em seus primórdios, o Romantismo Finlandês permaneceu amplamente enquanto interesse

\footnotetext{
6 Já em 1674, o Conselho de Antiguidades da Suécia-Finlândia buscava desvelar "importantes conquistas e feitos heroicos do passado", numa tentativa de glorificarem os feitos do reino Sueco. O Conselho resolveu, então, escrever para clérigos finlandeses nos limites de seu reino, ordenando que coletassem tais feitos de seus antepassados e os reportassem aos representantes do interesse sueco. Aos olhos dos finlandeses que se encarregaram dessa tarefa, surgiu um duplo efeito: de fato, rever as glórias de seus antepassados e resgatá-las iria alavancar a fama do reino Sueco-Finlandês como um todo; por outro lado, os colocava em contato direto com importantes feitos e conquistas especificamente finlandeses. Posteriormente, com o advento do lluminismo, essa visão crítica viria a se intensificar e começaram a surgir estudos sobre costumes locais, que passaram a sugerir o conceito de patria (em latim) como sendo a Finlândia, e não mais o reino Sueco-Finlandês como um todo. Incontornável exemplo desse processo foi a publicação, em 1789, da enciclopédia Mythologia Fennica, por Christfrid Ganander, que continha informações sobre costumes e crenças do povo finlandês, incluindo até mesmo passagens de poesias folclóricas. Apesar da importância em criar um senso de separação entre o que era finlandês e o que era sueco, o pensamento lluminista não se preocupava em defender ou exortar os valores de culturas individuais, favorecendo o desenvolvimento da ideia de uma cultura universal baseada na racionalidade, bom gosto e comedimento. A verdadeira conexão entre as tradições folclóricas e o nacionalismo - imprescindíveis para entendermos o surgimento da Kalevala - viria a ser estabelecida por influência do filósofo alemão Johan Gottfried Herder e do pensamento Romântico (TOLLEY, 2013, p. 115; WILSON, 1976, p. 29-30).

${ }^{7}$ Durante a Idade Média, a Suécia e o Grão-Ducado de Novgorod começaram ambos a manifestar interesse no território finlandês, esforçando-se para subjugá-lo política, econômica, cultural e religiosamente. Durante as Cruzadas no Báltico, entre os anos de 1150-1350 (durante os quais houve 3 grandes cruzadas contra os finlandeses) a Finlândia termina tornando-se parte do Reino Sueco (LIND, 2006, p. 436-338).

8 Segundo Herder, como o homem "origina-se em uma e de uma raça, seu desenvolvimento, educação e modo de pensar são genéticos" e, assim, "toda perfeição humana é nacional" (WILSON, 1976, p. 29). O nacionalismo defendido por Herder é um tanto quanto explícito, sendo passível de entendermos por que, segundo suas ideias, o desenvolvimento de uma nação exigia a separação entre o nós x eles.
} 
cultural - tendo inclusive sendo manipulado contra os próprios finlandeses, a favor dos russos -, tornando-se um movimento político e de emancipação apenas posteriormente, no século XIX (TOLLEY, 2013, p. 116).

Agora livres dos suecos, mas encurralados pelos russos, o resultado é uma crise de identidade entre os finlandeses (HONKO, 1990b, 189). Nesse sentido, a Kalevala surge paralelamente como instrumento de registro escrito das tradições orais que ainda circulavam entre os camponeses finlandeses em pleno século XIX, mantendo-as vivas por meio do fôlego da escrita, enquanto também apresentava, acima de tudo, a possibilidade de construção da identidade finlandesa por meio de um passado mítico comum a todo o povo finlandês, atuando na emancipação identitária e nacional do país (HONKO, 1990a, p. 8-10).

É necessário manter em mente que a absorção dos ideais Românticos por parte dos finlandeses foi algo que se deu em uma nação que não tinha uma literatura ou tradição literária em seu próprio idioma, mas que, por outro lado, era riquíssima em poesia oral (HONKO, 1990a, p. 8). Não demorou muito para que os Românticos de Turku ${ }^{9}$ percebessem essa lacuna e publicassem trabalhos como Suomen kansan wanhoja runoja (1822), por Zacharias Topelius, e Otava eli suomalaisia huvituksia (1829-1832), pelo já mencionado Gottlund. Ainda assim, não se pode dizer que as aspirações Românticas tenham sido alcançadas com esses trabalhos, principalmente porque as "verdadeiras" poesias folclóricas, ricas em intocável e pulsante conteúdo genuinamente finlandês, estavam em áreas interioranas e remotas de difícil acesso, em que esses autores não estiveram (TOLLEY, 2013, p. 116; WILSON, 1976, p. 24). Como o Romantismo tinha um elevado apreço por esse tipo de material folclórico ${ }^{10}$, algo inevitavelmente estava faltando.

\footnotetext{
${ }^{9}$ Nome dado à primeira leva de ativistas do romantismo finlandês, cuja localização do grupo era na cidade homônima.

${ }^{10} \mathrm{Na}$ Europa, o Romantismo criou um movimento folclórico extremamente forte, ao qual aderiram principalmente nações ainda jovens que buscavam suporte na criação de sua identidade cultural, como era o caso da Finlândia. Segundo o viés Romântico, o folclore era uma entidade criativa, ativa, que construía uma descrição do povo por si próprio; as experiências coletivas e humores típicos de uma nação estariam cristalizados e conservados nas palavras dos poemas e canções folclóricas. A poesia folclórica tradicional era vista como natural, criada pela e para a coletividade, em oposição à poesia lírica e artística, que era individual (HONKO, 1990a, p. 8-9). Essa visão do folclore não se limitou ao Romantismo, mas trouxe suas heranças até a antropologia dos séculos XX e XXI, a qual muitas vezes construiu a identidade de certos povos como o resultado de um processo de representações colaborativas, em que, o antropólogo, com certo olhar fetichista e desejoso de preservar ou dar voz a uma cultura, encara um representante da cultura (um cantor de tradições folclóricas, por exemplo) como vasilhame perfeito e representativo de toda a coletividade e identidade cultural de um povo, uma entidade viva que conserva uma cultura, mas que precisa de uma voz externa (a do antropólogo) para representá-la. Nesse processo o antropólogo ignora, por exemplo, a capacidade e possibilidade de que esses representantes do folclore criem e insiram elementos subjetivos em conteúdos folclóricos (algo que a própria tradição
} 
Esse espaço viria a ser preenchido justamente por Elias Lönnrot, que, ao ingressar na Universidade de Turku em 1822, bebeu dessa fonte e herdou suas influências. Nesse sentido, especialmente importante para a empreita que viria a ser conduzida por Lönnrot foram os princípios adotados por Sjögren: impressionado com as ideias de Herder a respeito do folclore e importando-as para o contexto finlandês, este passou a defender que as runosongs ${ }^{11}$ seriam as detentoras máximas desse conhecimento ancestral, antigo, e que nelas residiria a genuína voz do povo finlandês, chegando mesmo a coletar alguns materiais (PENTIKÄINEN, 1999, p. 18). Seriam exatamente as runosongs que Elias Lönnrot se aventuraria para coletar, usando-as como base de conteúdo da Kalevala.

O conteúdo que daria origem ao épico finlandês foi coletado por Elias Lönnrot ao longo de 11 viagens, feitas por ele às províncias orientais e do norte da Finlândia, entre os anos de 18281844. Na segunda edição da Kalevala, publicada em 1849, também foram incluídas canções compiladas por diversos outros coletores. É possível sabermos em maiores detalhes os métodos de trabalho adotados por Lönnrot, pois ele os descreve em seus diários de viagem e em alguns artigos publicados em jornais. Além disso, os poemas compilados por ele nessas viagens foram publicados na íntegra, sem alterações, no material Suomen Kansan Vanhat Runot (1908-1948), dividido em impressionantes 33 volumes. Isso possibilita que comparemos o material original com o épico que dele se derivou, o que nos ajuda a reconstruir o processo de manipulação de materiais vernaculares na composição de um épico. Isso pode, inclusive, esclarecer como surgiram outros grandes épicos em condições análogas (HONKO, 1990a, p. 9).

\footnotetext{
possibilita), tomando tudo que o representante faz como inerentemente coletivo e "tradicional". Essa questão é discutida em detalhes por Kristin Kuutma (2006), que investiga as representações criadas, por meio desses processos, a respeito dos povos Sámis e dos Setos.

${ }^{11}$ Runo era um termo êmico, tanto das tradições finlandesas quanto carelianas, para designar a poesia ou canção tradicional. A partir do século XVII, a palavra runo aparentemente começou a ser adotada para designar, em latim, o poemas tradicionais da Finlândia (runa, runo) e manteve-se sendo utilizada em palavras compostas também no idioma finlandês (runo-nuotti = melodia runo) e no sueco (runewijsor = canções runo). Posteriormente, no século XVIII, o termo runo é adotado de forma mais ampla para designar todos os tipos de poema compostos em métrica fínica (KALLIO, FROG \& SARV, 2017, p. 149). A runosong é uma tradição poética comum a inúmeros dos povos fínicos: esse sistema poético difundido amplamente entre esses povos detinha uma multifuncionalidade surpreendente e, apesar de se manifestar acima de tudo em canções, também é encontrado em provérbios, charadas, canções de ninar, encantamentos e lamentos. As propriedades poéticas que caracterizam a tradição das runosongs fínicas são a métrica trocaica (alternação entre posições de verso fortes e fracas) com quatro posições fortes por verso, e uma persistente ocorrência simultânea de aliteração e paralelismo, semanticamente vinculadas. Na região estoniana, o termo popular para essas canções é regilaul (SARV, 2015, p. 6). Evitamos a tradução de runo como runa, tanto para manter acessível o vernáculo que designa essa tradição, quanto para evitar confusões em relação ao que o termo "runa" designa no mundo germânicoescandinavo, algo que difere completamente do universo fínico.
} 
Em 1828, Lönnrot começou suas expedições de coleta das runosongs. Os primeiros lugares que visitou foram a Carélia Finlandesa e a Arcangel Carélia, depois da fronteira, onde a semelhança dialetal entre os idiomas falados e o finlandês era maior e, além disso, onde grande parte das populações eram imigrantes finlandeses. Lönnrot conseguiu isso aceitando um posto como médico em Kajaani, após ter completado seus estudos, pois sabia que lá poderia, nas horas vagas, dedicar-se à coleta desse material. Pouco tempo depois, a Sociedade Finlandesa de Literatura, fundada em 1831, começou a patrocinar financeiramente a empreita de Lönnrot. Podendo, então, continuar sua pesquisa, Lönnrot viria a fazer inúmeras outras viagens. Dentre essas, principalmente as que fez entre os anos de 1832-1837, para além das fronteiras finlandesas, na região da Carélia, seriam as mais importantes a nível de constituição do corpus kalevalaico (HONKO, 1990b, p. 194).

O fato de Lönnrot ter ido até o território da Carélia para buscar pelas runosongs (e, consequentemente, pela construção de uma identidade finlandesa) pode parecer controverso e até mesmo infrutífero. Primeiramente, essa foi uma imposição posta ao coletor pelo próprio contexto cultural: no século XIX, muito pouco dessa tradição oral havia sobrevivido. Ela havia sumido gradualmente dos maiores centros urbanos e comerciais, recolhendo-se para o interior. Como essa tradição oral carregava elementos que possibilitavam sua conservação e, nas regiões remotas mais ao norte, ela manteve ligações muito mais fortes com a magia, rituais e crenças o que a tornava seu apagamento por agentes externos mais difícil, pois entrelaçava-se a visões religiosas e mitológicas de mundo: por isso que grande parte dela estava preservada entre cantores épicos da Carélia Russa, por exemplo (FROG, 2014, p. 385-386). Outra razão para a preservação dessa tradição na Carélia era o letramento. No século XIX, a taxa de analfabetismo na Finlândia era de 20\%, o que obviamente terminou por criar um novo seguimento de entretenimento: a abertura de inúmeras editoras que começaram a publicar, dentre outras coisas, versões escritas de canções finlandesas. Enquanto isso, a taxa de analfabetismo na Carélia era de $92 \%$, ou seja, o entretenimento e a vida comunitária ainda giravam em torno desses cantores épicos que detinham, lá, outro status social, muito mais positivo do que na Finlândia, até porque o cristianismo, nesta, já estava muito mais consolidado (SIIKALA, 2000, p. 264). 


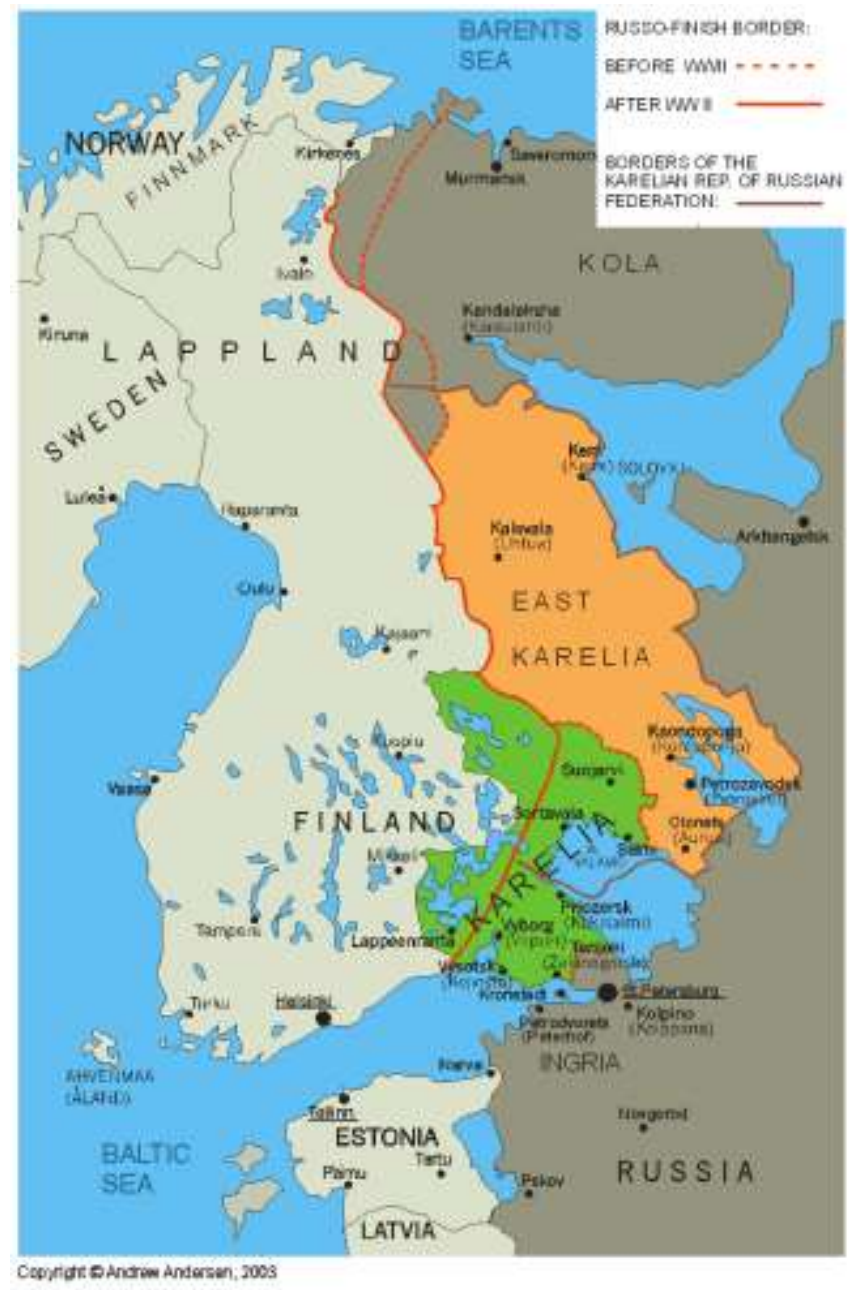

Figura 1: Mapa das fronteiras entre Finlândia, Carélia e Rússia ${ }^{12}$.

Mas então, se Lönnrot estava na busca de uma epopeia que resgatasse a memória e identidade finlandesas, porque escrevê-la com materiais coletados na Carélia? Apesar dos carelianos serem povos fínicos, a diferença entre eles e os finlandeses inegavelmente existiam. Então por que os cantos presentes no modo de vida de um povo tão ao leste, na fronteira, viriam a representar a Finlândia? Talvez o fato de que as runosongs fossem encontradas em ambos os lados da fronteira Finlândia/Rússia (ou melhor, Finlândia, Carélia Finlandesa e Carélia Russa) pode

\footnotetext{
12 Como o processo de coleta das runosongs por parte de Elias Lönnrot nos remete a essas localidades, inserimos um mapa para que o leitor visualize melhor. À esquerda, a Finlândia, cujas fronteiras com a Carélia estão divididas por uma linha vermelha (considerar a linha pontilhada onde ela o estiver, pois é ela que demarca as fronteiras antes da Segunda Guerra Mundial).Em laranja, a Carélia Oriental e, em verde, a Carélia Ocidental: em algumas fontes históricas e trabalhos acadêmicos elas são chamadas, respectivamente, de Carélia Russa e Carélia Finlandesa. Entre a parte laranja e a cinza, encontra-se a região da Carélia de Arcangel. A Carélia Oriental pode ser dividida em duas partes: ao sul, a Carélia de Olonets e, ao norte, a Carélia do Mar Branco, também chamada de Carélia Viena, de onde procedem a maioria dos materiais coletados para a Kalevala. Fonte: https://www.pinterest.co.uk/pin/238057530281209954/
} 
ter funcionado como uma ponte cultural, um código comum enxergado entre finlandeses e carelianos, processo que pode ter apagado certas diferenças (HONKO, 1990b, p. 182-183). Para as necessidades da época, parece que pouco importava. A Kalevala e os conteúdos que a compuseram - mesmo grande parte deles sendo oriundos da Carélia - não só foram concebidos como sendo símbolo máximo de tudo o que era inerentemente finlandês, como também foram recepcionados pela audiência então contemporânea como se de fato o fossem. Tanto é que, na época, tais perguntas de cunho regionalista sequer foram levantadas: o conceito de pátria e identidade, uma vez cristalizados, tornam-se sujeitos ao debate apenas quando não são mais auto evidentes por uma das partes (finlandeses ou carelianos, nesse caso). Por isso é que a discussão Carélia x Finlândia surgiu exclusivamente no meio acadêmico e apenas a partir dos anos 80 . Portanto, embebidos no contexto do Romantismo Oitocentista e buscando construir a identidade finlandesa - afastando-se de tudo o que fosse russo ou sueco -, materiais de ambas as localidades foram tidos por finlandeses ${ }^{13}$ (HONKO, 1990c, p. 571-572).

Felizmente, graças aos registros em seus diários de campo, sabemos um pouco sobre o método de anotação adotado por Elias Lönnrot. Não demorou para que ele percebesse que pedir para o cantor ditar a música era um método ineficiente, pois este precisava aguardar que o coletor terminasse de escrever para que ditasse a próxima linha: não só as palavras perdiam seu ritmo, melodia, métrica e entonação - afetados pelo ato nada natural de ditar -, como também os cantores menos experientes logo se perdiam, confundiam-se e não desejavam dar continuidade. Os mais experientes estavam aptos a contribuir com mais segurança, porém sempre sob o risco de esquecer ou encurtar versos. Como saída, Lönnrot, concebeu um método que o possibilitava anotar na mesma velocidade em que o canto natural seguia; ele colocava apenas as primeiras letras de cada palavra no papel. Com o tempo isso proporcionou a Lönnrot uma fluência absurda na linguagem e vocabulário épicos, a ponto até mesmo de conseguir antecipar o que o cantor iria dizer. Depois, sozinho, o estudioso editava os materiais, colocando

\footnotetext{
${ }^{13}$ O épico da Kalevala era algo que os suecos, por exemplo, não possuíam, e que sua cultura hegemônica não favoreceu de modo algum para que surgisse. De acordo com o elemento central defendido pelo Romantismo, cada nação possuía, em algum ponto, uma fonte embasada em sua linguagem mais pura, sua poesia mais verdadeira, mergulhada na verdadeira tradição: enquanto os finlandeses tinham as runosongs da Finlândia-Carélia, que precisaram ser resgatadas para compor a Kalevala, os suecos já tinham a poesia eddica e a mitologia nórdica, cujos conteúdos, segundo o Romantismo, já remetiam às suas raízes mais antigas e primordiais (HONKO, 1990c, p. 572).
} 
as palavras por completo. Já percebemos, com isso, que é impossível discutirmos a Kalevala como um projeto abstraído de processos de textualização e edição (HONKO, 2000, p. 18-19).

Muitas vezes, no entanto, Lönnrot recorreu a um ideal de unificação linguística. Para tornar o épico mais facilmente publicável e compreensível em uma ampla escala, ele não tolerou variações dialetais (que eram pequenas, porém inúmeras), que tornariam o texto, segundo ele, desnecessariamente mais difícil e complexo de ser entendido pelos finlandeses das regiões mais urbanas de Turku e Helsinque, por exemplo, pois estava repleto de regionalismos da Carélia ligados a um vocabulário muito específico do gênero épico interiorano (HONKO, 2000, p. 19). De certo modo, Lönnrot fez uma operação de universalização desse conteúdo épico, de fato necessária para que fronteiras linguísticas não atrapalhassem ou fragmentassem seu entendimento Finlândia Ocidental e afora, mas, por outro lado e paradoxalmente, esse processo resultou no apagamento de certas características e marcadores linguísticos peculiares da Carélia, na Kalevala (HONKO, 1990b, p. 210).

Duas condutas adotadas por Lönnrot que dificultam, por nossa parte, um entendimento melhor acerca das origens da Kalevala e suas runosongs, residem no fato de que ele não parecia estar interessado no contexto social e cultural em que esses poemas eram cantados e tampouco nos detalhes acerca das vidas e comportamentos dos cantores (HONKO, 1990b, p. 196). A nível de exemplo: sabemos, por meio de outras fontes e estudos comparados, que no período em que esses poemas foram coletados existiam, na Viena Careliana, dois tipos possíveis de habitus desses cantores, nem sempre uniformes e homogêneos, mas muitas vezes com misturas de ambos em alguma medida: o vocalista e o vidente. Os cantores possuidores do habitus de vidente favoreciam motivos e temáticas relacionados ao mundo mitológico, enquanto que o vocalista se distanciava da mitologia tradicional e favorecia oferecer uma performance mais melódica e harmoniosa. Essa diferença diz respeito não apenas ao modo de se executar a performance propriamente dita quando a hora chegava, mas ao tipo de registro poético, lexical e temático de que se lançava mão (SIIKALA, 2002a, p. 38-39). Pouquíssimas informações dessa espécie chegaram até nós por Elias Lönnrot.

Existem, na verdade 5 versões diferentes da Kalevala. As duas primeiras, coletadas e organizadas em 1833, não foram publicadas na época, mas apenas posteriormente, em 1891. A 
primeira delas continha algumas runosongs a respeito de Väinämöinen ${ }^{14}$, Lemminkäinen $^{15} \mathrm{e}$ alguns poemas do ciclo do "frequentador de casamentos" 16 , possuindo 3.191 versos. A segunda consistia em uma Coleção de Poemas sobre Väinämöinen, contendo 5.052 versos e agora apresentando a divisão em 16 cantos. Essa versão é conhecida, hoje, como a Proto-Kalevala. Em 1834-1835, surge a coleção Canções Antigas da Carélia a respeito dos Tempos Antigos do Povo da Finlândia, chamada também de Kalevala Antiga, que apresentava 32 cantos e 12.078 versos. Finalmente, em 1849 é publicada a Nova Kalevala, agora contendo impressionantes 50 cantos e 22.795 versos. A versão que chegou até nós nos dias de hoje, se consolidou e é amplamente discutida e analisada é justamente essa Nova Kalevala, conhecida simplesmente por Kalevala. Em 1862 foi publicada também uma versão reduzida a 9.732 versos para leituras do público infantojuvenil em escolas (FROG, 2014, p. 383).

Fica claro, portanto, o quanto Lönnrot estendeu o número de versos e conteúdo de maneira impressionante se compararmos a Kalevala Antiga e a Nova Kalevala - que aumentou quase o dobro -, distância que se amplia ainda mais se tomarmos a Proto-Kalevala como base. É interessante notar como essa empreita começou no momento em que Lönnrot, ao coletar as primeiras canções e notar o protagonismo frequente de Väinämöinen nelas, passou a visualizar uma era passada em que ele e alguns dos outros nomes mencionados fossem verdadeiras figuras históricas cujos feitos narrados pelos cantores eram de alguma forma verdadeiros. Nesse sentido, a intenção de fundo da Kalevala era, originalmente, uma grande descrição de Väinämöinen e suas aventuras. Isso influenciou até mesmo a estrutura da obra: o épico começa com seu nascimento e termina com sua partida - acompanhada, claro, da promessa de seu retorno. Isso apenas

\footnotetext{
14 Väinämöinen é o protagonista de grande parte das peripécias narradas na Kalevala, sendo inclusive responsável pelo surgimento do cosmos da maneira como o conhecemos. Ele é o principal herói das poesias épicas coletadas na Savônia e Carélia e muitas das suas estórias possuem temáticas fortemente xamânicas. A figura de Väinämöinen é basicamente a do demiurgo, do feiticeiro capaz de viajar ao mundo dos mortos para obter conhecimento, criador da música e de inúmeros utensílios mágicos (SARMELA, 2009, p. 539).

15 O Lemminkäinen da Kalevala, "sintetizado" por Lönnrot, era um corajoso e assumidamente imprudente herói em quem convergia o símbolo do grande cortejador guerreiro. Ele não enxerga qualquer problema em começar grandes guerras contra o poderoso povo de Pohjola ao ir até essas terras escuras do Norte para cortejar as mulheres de lá (o que chega até mesmo a ser motivo de sua morte, sendo ressuscitado às margens do Tuonela, rio dos mortos, por sua mãe). Contudo, o Lemminkäinen das runosongs também tinha um caráter fortemente xamânico que foi de certa forma apagado por Lönnrot mas que, ao que tudo indica, provavelmente era seu principal traço em tempos antigos, em meados da Era Viking (FROG, 2014; p. 386-340; SIIKALA, 2002b, p. 20).

${ }^{16}$ As temáticas do cortejo, o casamento e a preparação para sua celebração são muito frequentes na poesia folclórica finlandesa. Elas estão presentes não apenas na Kalevala, mas também em diversos poemas que Elias Lönnrot publicou sobre o nome de Kanteletar, que, para ele, eram de cunho mais lírico do que épico (KAUKONEN, 1990, p. 163).
} 
começou a mudar quando, entre um relato e outro acerca de Väinämöinen, Lönnrot inseriu dois episódios de Lemminkäinen e um de Kullervo ${ }^{17}$ (KAUKONEN, 1990, p. 160-161). Aos poucos, a Proto-Kalevala, centrada em Väinämöinen caminhou para se transformar num épico em que, apesar de ainda deter o lugar de protagonista, outros heróis e divindades oriundos das runosongs puderam figurar.

\subsection{Alguns prováveis modelos de Lönnrot, questões de textualização e gênero da Kalevala}

Para que possamos compreender os processos de textualização e, principalmente, a constituição da Kalevala enquanto gênero, necessitamos ter ciência de alguns dos modelos que Elias Lönnrot tinha em mente. Um erudito no sentido clássico do termo, Lönnrot era extremamente familiarizado com a literatura da Antiguidade, especialmente a helênica; a Ilíada de Homero era, em muitos aspectos, o modelo narrativo visado pelo autor finlandês. Ao compilar inúmeras das canções sobre Väinämöinen, Lemminkäinen e Kullervo - os dois últimos, como vimos, em menor número -Lönnrot percebeu que havia, nas entrelinhas, um berço temático que consistia no desenrolar narrativo das peripécias resultantes entre os conflitos do povo de Kaleva, os heróis, e o povo de Pohja, seus inimigos: o análogo finlandês dos gregos e troianos (KAUKONEN, 1990, p. 159; 161).

O próprio exemplo da atuação de Homero e da ideia da existência de alguém como ele, foi um fator que inspirou Lönnrot a desejar resgatar as narrativas histórico-mitológicas de seu povo e compilá-las num mesmo material, unificando-as num mesmo corpus coerente, ou seja, executando o trabalho artístico - análogo ao de Homero - de torna-las um épico (KUUSI, 1990, p. 133). Em uma carta datada de 2/12/1833, Lönnrot diz a um amigo que seu objetivo era "fazer uma coleção [de materiais] de aproximadamente metade da feita por Homero" (HONKO, 1990b, p. 200). É possível que Lönnrot não se visse apenas como coletor e organizados das runosongs, mas como um próprio cantor também, condensador, protetor e perpetuador dessa tradição, aquilo que o histórico Homero teria sido na Grécia. O argumento do finlandês, exposto em um artigo, era o de que, como a ordem dos diferentes poemas variava e se organizava de maneira

\footnotetext{
17 Talvez o personagem mais trágico do épico, Kullervo é a figura do anti-herói, que carrega uma história de escravidão, servidão, abusos e posteriormente, vingança.
} 
diferente de acordo com cada cantor, não havia como diferenciá-las e dizer qual ordenamento seria mais autêntico que os outros. Ele acreditava, então, que, uma vez tendo coletado inúmeras canções e tendo-as disponíveis em seu amplo e invejável repertório, ele também poderia ordenálas da maneira que quisesse, portando-se como um cantor e seu repertório ${ }^{18}$ (HONKO, 1990b, p. 218). A grande esperança de Lönnrot era de que, se o trabalho feito por ele não chegasse a constituir o que Homero tinha sido para os gregos, que então pudesse ser, ao menos, algo próximo a Hesíodo ${ }^{19}$ (VOIGT, 1990, p. 247; HONKO, 1990c, p. 556)

Ao lado dos cânones gregos proporcionados por Homero e Hesíodo, outra grande influência e modelo para Lönnrot era a Edda Poética ${ }^{20}$ dos nórdicos (HONKO, 1990c, p. 557). Ele descreve, em seu prefácio para a edição de 1835 da Kalevala, os esforços por ele feitos para que conseguisse coletar não apenas canções isoladas sobre Väinämöinen e outros heróis folclóricos finlandeses, mas "relatos mais longos também, como vemos entre os Gregos e os Islandeses e as músicas de seus antepassados". No século XIX, a Edda Poética tinha acabado de ser descoberta pelo círculo literário europeu e foi prontamente reconhecida como fonte de orgulho nacional não apenas para os islandeses, mas para todos os escandinavos, incluindo os suecos, cuja cultura ainda era predominante na Finlândia. A aproximação de Lönnrot com esse material foi certamente paradoxal: por um lado, tratava-se de uma fonte mitológica que representava o símbolo máximo do passado heroico sueco, povo dominador dos quais os finlandeses estavam tentando se distanciar por meio da construção de uma identidade propriamente finlandesa; por

\footnotetext{
18 "I could not regard the order chosen by one singer as more authentic than that of another, and explained this as springing from a natural desire to place his knowledge in some order, which varied according to the individual visions of different singers. Finally, since there was not a single singer able to compete with me in the number of poems I had collected, I believed I had the same right which, I was convinced, most singers permitted themselves to arrange the poems as I considered best, -- in other words I regarded myself as a singer, as their equal" (LÖNNROT, 1849, disponível em HONKO, 1990b, p. 218).

19 Outra influência do mundo grego na obra de Lönnrot era no modo como ele concebia o ordenamento e as relações entre as diferentes divindades mencionadas nas runosongs. Uma vez tendo essa empreita em mente, é possível que Lönnrot tenha buscado de maneira ativa evidências que corroborassem para a existência de um "Olimpo" finlandês em que todos os deuses fossem irmãos e um deles, mais poderoso, fosse a divindade suprema, paternal, soberana. Baseado nisso, então, ele chega à conclusão de que Ukko (originalmente divindade atmosférica e da fertilidade) fosse o grande deus supremo, enquanto que Väinämöinen, mesmo predominando nas narrativas das runas, estava mais para um herói cultural e grande sábio (PENTIKÄINEN, 1999, p. 159).

${ }^{20}$ Nome dado a uma coleção de 29 poemas escritos em nórdico antigo, encontrados num manuscrito chamado Codex Regius. 0 Codex Regius é datado da segunda metade do século XIII, sendo tradicionalmente considerado como cópia de um manuscrito mais antigo que o antecedeu. Este teria sido redigido até aproximadamente 1220 d.C., mas foi perdido. Seguindo os passos típicos da tradição oral germânica, os poemas eddicos são anônimos e não oferecem quaisquer referências sobre as circunstâncias de sua produção ou seu autor. Grande parte das composições poéticas presentes na Edda são oriundas da Islândia, mas algumas delas foram feitas também em países como Noruega, Dinamarca, Ilhas Britânicas e de fontes germânicas continentais (LANGER, 2015, p. 147-147).
} 
outro, o contato com a Edda Poética incentivou Lönnrot positivamente para que partisse em busca de um tesouro poético e mitológico similar, porém oriundo de seu povo ${ }^{21}$ (LÖNNROTH, 1990, p. 73).

Temos que considerar, ainda, que no século XIX vinculava a teoria, difundida por muitos acadêmicos, de que os poemas eddicos seriam da autoria de Sæmund, o Sábio ${ }^{22}$, um padre islandês que teria vivido no século XII. Acreditava-se que ele teria organizado canções nórdicas antigas sobre deuses e heróis lendários, unificando-as num corpus consistente: o Codex Regius ${ }^{23}$, que nada mais seria senão a apresentação desses eventos, relatos e narrativas em ordem cronológica, assim como Hesíodo havia feito em sua Teogonia. Ao sair para coletar as runosongs, Elias Lönnrot provavelmente desejava desempenhar o papel do próprio Sæmund, visando organizá-las em seguida num todo coerente. Nesse sentido, a imagem do suposto coletor das canções nórdicas e organização do Codex Regius tornava-se análoga à de Elias Lönnrot e o ordenamento das canções finlandesas para composição da Kalevala (LÖNNROTH, 1990, p. 86-87). Fosse Homero, Hesíodo ou Sæmund, o emblema do poeta guardador da tradição oral, que também a canaliza para a linguagem épica, era o ideal de Lönnrot. Curiosamente, outros modelos germânicos de épico, como o Das Nibelungenlied ${ }^{24}$ (A Canção dos Nibelungos), não exerceram nenhuma influência perceptível nos ideais de Lönnrot ou na composição de sua obra, talvez por seu pouco conhecimento do idioma alemão (FROMM, 1990, p. 93-97). São detectadas também influências cristãs na obra de Lönnrot, embora menores, apesar de mais óbvias ${ }^{25}$.

\footnotetext{
${ }^{21}$ Ainda que os materiais que deram origem à Edda Poética e os que deram origem à Kalevala sejam de naturezas completamente distintas, constituindo materiais folclóricos completamente diferentes.

22 Inclusive, na época esse material não era conhecido por Edda Poética, como hoje em dia, mas como A Edda de Sæmund.

${ }^{23}$ Consultar nota 22.

${ }^{24}$ Escrita por um poeta anônimo durante 1.200, esse é o maior poema/balada heroica medieval germânica da Idade Média. A narrativa foca no exterminador de dragões Sivrit e seu cortejo da bela Kriemhilt; e, paralelamente, do Rei Gunther e sua atração pela Rainha Prünhilt (EDWARDS, 2010, p. xi).

${ }^{25}$ As mais óbvias delas são, na Kalevala, o ciclo de Marjatta (Maria), a virgem da terra de Kalevala que engravida ao comer uma lichia. Seu filho, uma figura que claramente representa Jesus, é condenado à morte por Väinämöinen por ter nascido fora de um casamento: contudo, o menino termina sendo coroado Rei da Carélia, o que causa a partida definitiva de Väinämöinen para terras distantes (substituindo um deus pagão pela chegada de um menino nascido de uma virgem, temos a clara alegoria do advento do cristianismo sobre o paganismo). Há ainda outras influências, menos explícitas: influenciado pelo Antigo Testamento, Lönnrot defendia que os antepassados do povo finlandês eram descendentes de uma proto-tribo dos Montes Urais, que também buscavam por sua terra prometida: a Carélia. Daí vem o nome da Finlândia em idioma vernacular, Suomi, que significa "prometida" (HONKO, 1990a, p. 158-159). Precisamos também ressaltar o fato de que, em seu prefácio para a primeira versão da Kalevala, o Lönnrot alega que o paganismo de seus antepassados não era do pior tipo, e mais; ele também defendia que a religião primordial dos antigos finlandeses teria sido monoteísta e que o único e supremo deus dentro desse sistema religioso teria sido Ukko. De acordo com essa visão, a religião finlandesa antiga cultuava e reconhecia, originalmente e por natureza, apenas um deus, mesmo posteriormente, quando outras divindades surgiram. Foi por isso que Lönnrot chamou a religião de seus antepassados como um
} 
Portanto, quando pensamos no processo de textualização e de edição das runosongs por parte de Lönnrot, devemos manter em mente esses modelos anteriores na mente do finlandês: elas não se converteram da oralidade para a escrita épica em seu formato bruto. Por um lado, conforme o finlandês coletava os materiais oriundos das runosongs, percebia grandes eixos temáticos dotados de certa narratividade, ou seja, parecia já haver certa consistência de ciclos épicos antes mesmo de sua interferência, como, por exemplo, o Ciclo do Sampo ${ }^{26}$ (KUUSI, 1990, p. 136). Ainda assim, foi necessário o papel ativo de Lönnrot, que conectou esses poemas mitológicos pré-literários para formar uma série de acontecimentos, cenas e personagens que estavam todos irrecusavelmente ligados a uma trama maior, esta, de cunho épico: a luta dos filhos de Kaleva contra os habitantes da sombria Pohjola. Foi por meio desse empenho consciente de Lönnrot que diversos Ciclos ou Semi-Ciclos mitológicos - como A Canção da Criação; O Cortejo da Filha do Norte; O Ciclo do Casamento e o já mencionado Ciclo do Sampo - foram unificados num mesmo corpus temático. A Kalevala é, segundo esse ponto de vista, uma poesia da poesia (KAUKONEN, 1990, p. 164).

Lönnrot encarava esse processo criativo e de textualização dos conteúdos vendo a si mesmo como um cantor das tradições ${ }^{27}$. Apelando para a liberdade que os cantores das runosong manifestavam, adotando-a também para si, ele conscientemente afastou-se do modelos de compilação empregados por alguns desses poetas orais e, sobretudo, da improvisação que existia e era característica nas canções antigas de cantores que lhe forneceram muitos de seus conteúdos, como Arhippa Perttunen e Ontrei Malinen. Basicamente, as mudanças elaboradas por Lönnrot se deram quando o finlandês se permitiu eliminar incoerências e inconformidades que surgiam ao comparar diferentes poemas sobre os mesmos personagens (ou variantes regionais

\footnotetext{
"bom paganismo", que em seu próprio passado pré-cristão já teria sido monoteísta, o que facilitou a assimilação posterior do cristianismo. Ou seja, de certa forma, Lönnrot defendia que a religião primeira do povo finlandês teria sido uma espécie de monoteísmo primordial (PENTIKÄINEN, 1999, p. 77)

26 Um Ciclo épico pode ser constituído pela fixação e interação de diferentes motivos, encontrados ou não em poemas isolados. Nos Ciclos, poemas de diferentes heróis e divindades e seus respectivos mitologemas peculiares podem mesclar-se, formando narrativas maiores e mais complexas. No caso do Sampo, misturam-se narrativas de Väinämöinen, Leminkäinen e Ilmarinen que, juntas, passam a contar da criação, do roubo e do resgate desse poderoso artefato mágico, bem como das inúmeras consequências acarretadas por cada um desses atos (KUUSI, 1990, p. 159).

${ }^{27}$ Curiosamente, em sua introdução à compilação de poemas líricos Kanteletar, Elias Lönnrot diz que os poemas não feitos, mas que eles se fazem a si mesmos, nascendo, crescendo e tomando forma independentemente de qualquer intenção ou cuidado especial por parte de um criador (o poeta), que é apenas seu veículo transmissor. Este é um conceito fortemente relacionado à visão do Romantismo (HONKO, 1990b, p. 213).
} 
do mesmo poema), interpolando-as ou escolhendo uma para prevalecer sobre as demais e adicionar, nos poemas ao longo da Kalevala, referências a poemas e cantos anteriores. Alguns elementos evidentemente cristãos foram eliminados, numa tentativa de arcaizar os temas (por isso a ocorrência de Marjatta e seu filho apenas já no fim da epopeia); e houve também um esforço por adicionar dramaticidade à narrativa ao enfatizar a tensão base do épico, que eram os conflitos, evidentemente alegóricos do nacionalismo, entre os interesses de Kaleva e Pohjola. Além disso, as cenas de batalha e atos de violência também receberam uma ênfase que não existia na tradição oral e, vale lembrar, também houve acréscimo de conteúdo oriundo de outros gêneros orais, como encantamentos. É acima de tudo essa combinação de gêneros distintos da oralidade que distinguem a Kalevala da poesia folclórica genuína. Essas mudanças se deram acima de tudo, vale ressaltar, no momento de elaboração da Nova Kalevala (KUUSI, 1990, p. 151-152).

Por mais que Lönnrot não tenha inventado conteúdos, personagens, narrativas e temas no sentido estrito do termo, foram essas supracitadas modificações que moldaram o conteúdo oriundo das runosongs e outros gêneros orais para o formato épico, passando pelo processo de textualização e edição por parte do autor. Essa textualização dos épicos orais desencadeia uma situação em que acabamos por lê-los em formatos que eles nunca revelaram ter possuído originalmente, quando circulavam em formato oral na vida real. É esse cuidado que precisamos ter ao nos aproximarmos da Kalevala: o de que a performance vernacular e a textualização do épico são processos distintos e até mesmo separáveis (HONKO, 1990a, p. 5). Certamente que isso não implica em conclusões precipitadas e desequilibradas, como as defendidas por Alan Dundes (1985), que dizia não haver nada de autenticamente folclórico na Kalevala, mas apenas falsificações, fakelore ${ }^{28}$. Nesse sentido, discordamos veementemente de tais posições e nos alinhamos ao questionamento de Honko (1990b, p. 226): falsificações do que? Essa alegação de falsificação parece estar muito mais preocupada em defender justamente um ideal Romântico de épico do povo, do que em debater e tentar compreender os processos de elaboração, textualização e recepção dos grandes épicos de base oral.

\footnotetext{
$28 \mathrm{O}$ autor defende o uso da palavra fakelore em oposição a folklore, mantendo a raiz -lore (conhecimento, saber) mas substituindo folk (povo) por fake (falso), formando algo como falso saber.
} 
E, afinal, permanece a pergunta: como classificar a Kalevala? A que gênero específico pertence a obra de Lönnrot? Definir épico como um único gênero talvez seja perigoso e nos empurre para tradições conceituais problemáticas, herdadas do próprio Romantismo. Certamente a noção de épico atua como um guarda-chuva conceitual debaixo do qual inúmeras características e traços podem ser abrigados como, por exemplo, a necessidade de um enredo coerente e narração em terceira pessoa, mas variações são toleradas (HONKO, 1990a, p. 6). Apesar de inúmeros estudos de caso e análises empíricas dos épicos oriundos de diferentes partes do mundo e períodos históricos terem mostrado cada vez com mais força que o destino das generalizações tipológicas é o de se mostrarem em alguma medida insustentáveis (HONKO, 1990a, p. 3), convém reconhecermos que diversas obras podem ser categorizadas dentro da categoria épico por compartilharem determinadas características, embora manifestem simultaneamente inúmeras diferenças, até mesmo a respeito da natureza de sua composição. Algumas dessas obras possuem semelhanças mais acentuadas com certas outras, o que nos permite pensar em uma espécie de "subgrupos épicos" de acordo com a afinidade. Por esse motivo trazemos a definição de Hatto (1980, p. 11), segundo o qual existiam 4 categorias de épico: 1) épicos orais (como os dos povos Ainu, dos Mongóis ou os do Servo-Croatas); 2) sub-orais (as obras de Homero, por exemplo); 3) pós-orais (os épicos da França e da Espanha medievais, também o caso em Das Nibelungenlied) e 4) épicos secundários (A Eneida, Paraíso Perdido).

Talvez a Kalevala se aproxime mais de um épico pós-oral, considerado o modo como ela encontra-se atada às normas de expressão da oralidade ditadas pelo cantar épico das runosongs que foram coletadas por Lönnrot, porém com adendo de que tal conteúdo passou por processos de textualização e edição por parte do finlandês, que as colocou no mesmo corpus coerente e as publicou visando não com que fossem cantadas conforme formato original, mas sabidamente para que fossem lidas (HONKO, 1990a, p. 19). Ao olhar a Kalevala como um épico da pós-oralidade evidenciamos o fato de que, apesar de ter se originado de canções performatizadas, o seu conteúdo final, depois de escrito, supera uma única performance que encontraríamos no 
contexto original ${ }^{29}$ (HONKO, 2002, p. 7). Ou seja, a epopeia finlandesa alinha-se à categoria tradicional de épico no sentido de que preserva certas características da oralidade e suas tradições; porém, tendo sofrido os processos de textualização e edição por parte de Lönnrot, seus conteúdos tornam-se uma espécie de cantar secundário, no sentido de que sucede as runosongs (HONKO, 2000, p. 37). Nesse sentido, a Kalevala é uma espécie de corpus pós-performático, um conteúdo oriundo das tradições orais e a elas fiel em alguma medida, mas que, no entanto, não as representa em sua inteireza, apresentando as marcas estéticas e textuais da literatura.

Ao que tudo indica, o épico de Lönnrot parece estar destinado a transitar entre o épico literário e o folk epic ${ }^{30}$, ocupando ora o lugar de um, ora o de outro e, por isso, pode ser que seja injusto categorizá-lo em apenas uma dessas taxonomias, o que levaria com que características importantes fossem apagadas ou deixadas de lado. A Kalevala parece ser ambas as coisas, pois abarca esses dois processos em alguma medida, seja em sua origem entregue pelos cantores épicos (performando as runosongs), seja por Lönnrot, que anotou, coletou e editou tais conteúdos (HONKO, 1990a, p. 24-25). Considerados esses detalhes, principalmente ao pensarmos no campo de estudos comparados dos grandes épicos, a Kalevala não pode ser comparada aos épicos puramente literários (HONKO, 1990b, p. 182). Vemos, aqui, a diferença fundamental entre estes e os folk epics: os criadores do segundo não são donos ou mestres de seu material, mas falam por meio de uma "voz maior", nesse caso, a voz da grande tradição poética da qual beberam e são devedores. Mesmo visando a criação de um grande épico do povo finlandês, Elias Lönnrot tinha suas mãos atadas e precisava alcançar seus objetivos trabalhando apenas com o material que tinha disponível - a tradição oral oferecida pelos cantores épicos das runosongs - (HONKO, 1990c, p. 562).

\footnotetext{
${ }^{29}$ Precisamos pensar além da dualidade excludente oralidade vs. textualização: a textualização de tradições orais é capaz de acomodar estéticas literárias enquanto conserva características impostas pela oralidade (HONKO, 2002, p. 5).

${ }^{30}$ Evitamos nesse artigo a tradução de dois termos: folk epic e tradition-oriented epic, por acharmos que seu correspondente em português não alcança o sentido pretendido pelos termos. Por folk epic entende-se um épico embasado no folclore, porém numa noção de folclore lato sensu que vai além do segmento, extremamente específico, daquilo que no Brasil chamamos de folclore. $\mathrm{Na}$ tradição acadêmica, sobretudo finlandesa, folclore é um tipo específico de saber que embasa uma visão de mundo e o modo de entendê-lo, interpretá-lo, categorizá-lo e qualificá-lo. Épico folclórico ou épico popular parecem ambos deixar algo de lado ao tentar passar esse significado. O mesmo acontece com tradition-oriented epic. Por tradição entende-se todo o corpus de símbolos, rituais e práticas, orais ou não, que embasam o entendimento de um povo acerca do mundo circundante, noção essa que abarca inclusive o próprio folclore. A palavra oriented, nesse caso, é difícil de ser traduzida, pois não significa exatamente que a tradição norteie ou oriente o épico (conforme vimos, Lönnrot teve a liberdade de editar e modificar como bem quisesse o conteúdo coletado por ele), mas que ela é o material primordial, que antecedeu e embasa o épico. Dadas essas ressalvas, decidimos manter ambos os termos conforme lemos no original, em inglês.
} 
Portanto, a Kalevala deve ser vista como estando mais alinhada a um folk epic, já que suas linhas não foram criadas por Lönnrot, mas apenas editadas. É importante ter em mente que os conteúdos e narrativas, da forma como estão na epopeia, possuem seus correspondentes ${ }^{31}$ na tradição e na poesia oral, com a qual podem ser contrapostas e comparadas (HONKO, 1990b, p. 208). No que diz respeito à taxonomia e às questões de gênero da Kalevala, considerado o que foi agora posto, nos alinhamos, então, à proposta de Lauri Honko $(2000$, p. 7$)$ de classificá-la como tradition-oriented epic. Tratam-se dos épicos que possuem discursos anteriores, na forma de poesia oral (no caso finlandês, das runosongs), internalizados primeiramente pelos performadores (os cantores) e, em seguida, pelos editores, escribas ou autores responsáveis por textualizar o material de acordo com o registro literário. Uma vez surgidos, esses tipos de épicos, apesar de oriundos da oralidade e suas tradições, não são documentos que revelem direta, completa e fidedignamente a performance oral. É importante notar também a distância entre o material performado originalmente em seu contexto natural e o texto final apresentado pelo épico: poeticamente, este é um segundo texto que, apesar de não ser um registro fiel da oralidade, é intrinsecamente orientado por essa tradição 32 .

\subsection{0 contexto mitológico e xamânico da Kalevala}

É consenso, entre os estudiosos da Kalevala, que esta se trata de um grande épico mítico e xamanístico 33 (HONKO, 1990a, p. 24); assim, apesar de constituir uma epopeia, seu enfoque não encontra-se nas narrativas de feitos heroicos no sentido estrito da palavra, mas no desenrolar de peripécias que exigem, muitas vezes, soluções buscadas por meio da empreita xamânica, ou seja a obtenção de soluções advindas do mundo dos mortos, cuja fronteira é cruzada por alguém vivo (OINAS, 1978, p. 293). Conforme apontamos anteriormente, segundo esclarecido por AnnaLeena Siikala (2002a, p. 38-41; 2000, p. 258-262), não havia uniformidade no habitus dos cantores

\footnotetext{
31 Além da Kalevala e suas diferentes versões, Elias Lönnrot publicou todos os poemas originais que coletou, na íntegra. Atualmente eles estão preservados na coleção de 33 volumes chamada Suomen Kansan Vanhat Runot 1908 - 1948, infelizmente ainda sem tradução para o inglês. O interessante é que uma publicação desse tipo, paralela à da epopeia, nos permite acompanhar os passos do autor e contrastar o modo como certas narrativas ou temas encontram-se na Kalevala e na tradição oral, o que é uma grande vantagem e um fato um tanto quanto único (HONKO, 1990a, p. 9).

32 Dentre outros épicos que se encaixam nessa categoria encontram-se Gilgamesh; os épicos Homéricos; os indianos Rāmāyaṇa e Mahābhārata;o iraniano Shähnäme; além de outros como Beowulf, O Cantar de Mio Cid, A Canção de Rolando, Das Nibelungenlied e as Eddas (HONKO, 2002, p. 7).

${ }^{33}$ Apesar de na epopeia não aparecer, nenhuma vez, a palavra "xamã" ou outra correspondente (LA FUENTE, 2006, p. 42).
} 
rúnicos que forneceram material épico a Lönnrot: alguns deles se alinhavam aos ideais do vocalista, classe envolvida com o entretenimento fortificador dos laços comunitários, embora também preservadora de temáticas tradicionais; e o vidente, preocupado com a aplicação de conhecimentos mitológicos e encantamentos capazes de afetar a comunidade. A diferença entre ambos era perceptível nas canções a nível temático (o cantar do vidente priorizava os acontecimentos mitológicos envolvendo divindades e o emprego de metáforas sobre o outro mundo); o comportamento corporal durante a performance; os registros de linguagem específicos, léxico e arcaísmos. Trataremos da influência dos cantores videntes no que foi registrado por Lönnrot e mantido na epopeia finlandesa. Para estes, o cantar épico era usado com funções ritualísticas do mesmo modo como os encantamentos o eram: descrever e narrar os atos mitológicos transferia suas ações e impactos para o momento presente (SIIKALA, 2002a, p. 34).

Os responsáveis por esses cantos épicos de temática mitológica ligada a rituais e a encantamentos eram os tietäjä̈ ${ }^{34}$ (em finlandês, "aquele que sabe"), que atuava como uma espécie de especialista em rituais. O papel dessa figura na sociedade, que atuava em rituais de cura, proteção e até mesmo de ofensiva contra outras comunidades, bem como o seu conhecimento e suas tecnologias ritualísticas/mágicas de encantamentos diversos são, juntos, designados de instituição tietäjä. Apesar de lançar mão de encantamentos, recitações, técnicas de êxtase e viagens astrais para outros mundos (principalmente o dos mortos), os tietäjä não eram xamãs no sentido estrito do termo e foram, na verdade, uma instituição que surgiu historicamente em oposição aos resquícios do xamanismo clássico ${ }^{35}$, que ainda imperava na Finlândia e na Carélia medievais, sendo por isso considerado uma instituição pós-xamânica ${ }^{36}$.

\footnotetext{
${ }^{34}$ A palavra tietäjä claramente é derivada do verbo tietää ["conhecer"] com um afixo agentivo, significando de maneira literal "conhecedor, aquele que conhece". Ela é apenas uma dentre uma variedade de outros termos vernaculares que designam os especialistas rituais, termos estes que podem ser ligados a práticas, tecnologias, habilidades ou papéis sociais específicos (FROG, 2019, p. 243).

${ }^{35}$ A discussão em torno do conceito de xamanismo é extremamente extensa e não nos compete fazê-la aqui. Esse termo é empregado de modo tão amplo e abrangente por estudiosos como Eliade (...) que acaba por ter pouca significância, ainda mais no contexto comparativo. Entenderemos, aqui, o "xamanismo clássico" como um fenômeno transcultural das sociedades nômades do Ártico, caracterizado por um complexo de características dentre as quais se encontram a estrutura e organização social típica das culturas de caça; uma cosmologia específica e o uso do tambor em conexão com comportamentos de êxtase (HULTKRANTZ, 1973). Os tietäjä não faziam uso cerimonial de tambores e viviam imersos numa sociedade já agrária e sedentária, com organizações sociais típicas destas.

${ }^{36} \mathrm{~A}$ instituição tietäjä provavelmente começou a surgir no Período Merovíngio, quando os contatos com povos germânicos ainda eram intensos, o que explica a cristalização de certos ocidentalismos germânicos detectáveis no léxico de encantamentos da região da Carélia ainda no século XIX, que teriam, pelo isolamento da região, se preservado. Na Finlândia, da Idade Média em diante, o xamã passou a ser chamado de noita (palavra também relacionada ao sámi noaidi - xamã) e recebeu uma carga negativa
} 
Mais do que um xamã, que na Finlândia Moderna já tinha conotação negativa por conta de influências cristãs, a figura do tietäjä estava mais para a de um sábio versado na arte da magia recitada e da cura (SIIKALA, 1990, p. 192). Ainda assim, a mitologia kalevalaica era a própria mitologia do tietäjä (FROG, 2014, p. 404).

Como essa discussão carece de um espaço de que não dispomos, gostaríamos apenas de elencar alguns dos grandes temas mitológicos encontrados na Kalevala que revelem possuir origens no conhecimento dos tietäjä e em seu emprego de encantamentos. A representação da figura do tietäjä e suas habilidades xamânicas encontram-se representadas, acima de tudo, no deus demiurgo Väinämöinen e no ousado Lemminkäinen (LA FUENTE, 2006, p. 43-45). Um dos temas mais presentes nos versos da Kalevala é a respeito das jornadas de Väinämöinen ao mundo dos mortos, Tuonela. Geralmente ele o faz em busca de palavras mágicas ou da obtenção de conhecimentos que só podem ser encontrados terras, após cruzar as mórbidas correntezas do rio que separa os vivos da morada dos mortos. Uma vez em Tuonela, onde a comida é veneno para os homens e cobras rastejam pelas camas, Väinämöinen se depara com a filha de Tuoni (senhora de Tuonela) e ela relata sua surpresa ao notar que o sábio não mostra sinais de morte. Ora, a habilidade de transitar para o mundo dos mortos mesmo vivo e de lá regressar com o conhecimento necessário é justamente a habilidade do tietäjä e o motivo pelo qual ele era requisitado na sociedade Fino-Careliana Moderna. O Väinämöinen das runosongs dos tietäjä, com suas idas à morada dos mortos em busca de sabedoria, era uma espécie de arquétipo cultural, de modelo heroico e exemplar a ser adotado por eles. Ele era visto como um tietäjä primordial, pai fundador da tradição (SIIKALA, 2002a, p. 171; 302). Por isso que, em diversos encantamentos, o tietäjä se dirigia diretamente a Väinämöinen, invocando-o no começo do ritual:

Surja, velho Väinämöinen, homem ancião, acorde de seu sono, somente para ser a ajuda deste homem,

de outsider, tornando-se uma figura que passou a ser vista com medo, desconfiança e recriminação. Tanto é que a palavra noita passaria, depois, a virar o termo comumente aceito para designar "bruxa(o)". Ou seja, desde a consolidação do cristianismo em terras finlandesas, vemos duas instituições mágicas ocorrendo paralelamente: a dos tietäjä e a dos noita, de certa forma opostas e competindo para sobreviverem. Como a instituição tietäjä se afastava do xamanismo ártico clássico, ao contrário dos noita, sua capacidade de absorção e negociação de elementos cristãos era maior, ou seja, de maior adaptabilidade. Deuses como Ukko mantiveram-se, por exemplo, em seus encantamentos, mas absorvendo características do onipotente deus cristão. Aos olhos dos cristãos (fossem os que estavam no poder, fossem os campesinos já convertidos) a instituição tietäjä foi uma espécie de "menor dos dois males" e era vista com mais tolerância. Assim, durante a Idade Moderna os noita sofreram perseguições religiososimbólicas até extinguirem-se, enquanto que os tietäjä mantiveram-se até o século XIX, na época de coleta de Lönnrot (FROG, 2014, p. 404; 2017, p. 87-90). 
a companhia deste homem morto

durante esta tarefa árdua

dessa magia tão difícil! (...)

(SIIKALA, 2002b, p. 195);

Venha, velho Väinämöinen, venha cá, onde há necessidade, para resolver esses problemas!

Suas sábias palavras são as mais antigas de todas"

(SIIKALA, 2002b, p. 209)

Por vezes, o tietäjä se preparava para sua atuação pedindo que Väinämöinen auxiliasse trazendo equipamentos mágicos como vestimentas, ou até mesmo emprestando seu cavalo:

O manto do velho Väinämöinen

a capa do Lapão distante

deixe que seja trazida aqui (...)

ela traz proteção na guerra

atrás dela eu lutarei (SIIKALA, 2002b, p. 287);

Eu [o tietäjä] pego o cavalo de Väinämöinen (...), ele passa sibilando pelos pinheiros

seus cascos não afundam

nem mesmo nas lâminas de gelo celestial

nem mesmo no abismo de kalma

no seu caminho para a casa!

(SIIKALA, 2002b, p. 234).

Na Kalevala, assim como Väinämöinen, o herói Lemminkäinen faz diversas jornadas ao mundo dos mortos. Seu intuito, contudo, é diferente: ele frequentemente o faz em busca da oportunidade de cortejar uma das filhas de Louhi (senhora de Tuonela) durante os banquetes oferecidos em Päivolä, fazenda localizada no outro mundo. Sua mãe é descrita diversas vezes tentando evitar sua partida, advertindo-o dos perigos que o aguardam, até o momento em que Lemminkäinen de fato morre ${ }^{37}$ e necessita ser ressuscitado por sua mãe ${ }^{38}$. Em diversos contextos, para superar obstáculos tipicamente impostos à jornada xamânica no contexto fínico, como andar sobre caminhos de lâminas afiadas, vencer o fogo e fugir de cães sobrenaturais, Lemminkäinen entoa canções mágicas ou até mesmo transforma-se em pássaro, ambas características clássicas

\footnotetext{
${ }^{37}$ Assim como Baldr da mitologia nórdica, Lemminkäinen sofre sua morte pelas mãos de alguém cego.

38 Talvez mostrando a heritariedade dos poderes xamânicos de Lemminkäinen.
} 
de poderes xamânicos (FROG, 2014, p. 405); as peripécias narrando sua trajetória para o mundo dos mortos, buscando esposas, também é oriunda de canções que nos revelam essa camada de crença xamânica, em que aquele com as habilidades e conhecimento necessários é capaz de cruzar o rio que separa os vivos dos mortos (SARMELA, 2009, p. 311).

Nas runosongs existem variantes que descrevem de modos diferentes as jornadas e intuitos de Lemminkäinen, mas que ainda assim parecem reter o simbolismo alinhado ao xamanismo. Numa dessas canções, resolvendo ir à uma fazenda no mundo dos mortos sem ter sido convidado (chamada em algumas versões de Päivölä e, em outras, de Väinölä), Lemminkäinen é morto durante uma competição de canto contra um tietäjä e sua mãe tenta ressuscitá-lo. Em outra versão, uma vez nessas terras, Lemminkäinen desafia um habitante para duelar e o vence, cortando sua cabeça com uma espada. Em seguida ele consegue retornar para casa e, seguindo o conselho de sua mãe, navega rumo à ilha das mulheres (HARVILAHTI; RAHIMOVA, 2012, p. 73). Considerando as duas versões parecemos encontrar, respectivamente, uma que possui a função pedagógica de ensinar sobre os perigos e possíveis consequências de se desafiar um tietäjä para uma competição de canto, não importa o quão poderoso se acredite ser; a outra, pelo contrário, remete aos espólios que aguardam aquele que ousa ir até o mundo dos mortos sem convite, subjugando as forças dos habitantes - os próprios mortos -.

É possível que as runosongs figurando Lemminkäinen fossem cantadas especialmente em cerimônias de casamento, como rito preventivo em prol de propiciar boa fortuna ao recém casal. Considerando os diversos cortejos e busca por esposas da parte de Lemminkäinen em diversas canções épicas e na Kalevala, somadas ao fato de que muitas delas eram entoadas nesse contexto supracitado, é possível que estejamos diante de reminiscências de um culto antigo da fertilidade, que provavelmente estivesse em vigor durante a Era Viking (SIIKALA, 2002b, p. 310-315).

Outro exemplo que poderíamos elencar é o deus finlandês dos trovões, Ukko, que na epopeia de Lönnrot não possui protagonismo em nenhuma parte da narrativa, mas que assumiu o caráter de um deus supremo intervencionista ${ }^{39}$ (PENTIKÄINEN, 1999, p. 77; 159), além de ter

\footnotetext{
${ }^{39}$ Nos materiais coletados por Lönnrot, Ukko surgia como divindade da esfera celestial, regente dos ares, mantenedor da abóbada celeste e, acima de tudo, governante dos raios e tempestades, Lönnrot viu sentido em atribuir a essa divindade celestial dominadora dos céus a posição de divindade suprema para assemelhar o panteão finlandês ao Olimpo grego. Talvez os trovões de Ukko tenham despertado em Lönnrot uma afinidade comparativa em respeito aos trovões de Zeus. Assim, Ukko aparece na Kalevala como o deus supremo de um Olimpo pressuposto e em torno do qual a hierarquia de todos os outros deuses foi
} 
sido o responsável pela criação do $\operatorname{cosmos}^{40}$ (KAUKONEN, 1990, p. 173). Ao tentar cumprir os desafios postos por Louhi para que permita sua filha casar-se com Lemminkäinen, o herói não raramente passa por situações críticas de perigo eminente que aparentam não ter saída. Nesses momentos ele apela diretamente a Ukko, invocando e pedindo por ajuda. Esse deus supremo, então, o auxilia, em geral por meio da manipulação de fenômenos climáticos e atmosféricos a seu favor - causando tempestades, raios, tormentas, chuvas de granizo, de neve, surgimento de neblina, névoa, nuvens -. Outras vezes ele confere armamentos mágicos a Lemminkäinen, como uma espada flamejante (ALVES, 2019, p. 138-148; 195-202).

Vários encantamentos postos em uso pelo tietäjä invocavam a ajuda de Ukko, principalmente em situações que envolviam o combate - obviamente que no plano espiritual contra outro xamã. Eram pedidas intervenções atmosféricas, e mais: ele também os conferia equipamentos protetivos e armamentos mágicos - machados, flechas, espadas flamejantes - e erguia uma cerca mágica protetiva em torno do tietäja de forma que xamãs adversários não conseguissem atravessá-la nem por cima, se adquirissem a forma de pássaro, nem por baixo, se estivessem na forma de serpente (SIIKALA, 2002b, p. 94-100; 204-207; FROG, 2019, p. 256-260). Percebemos claramente que, na Kalevala, Lemminkäinen (que, como vimos, possui traços xamânicos) pedindo pela ajuda e intervenção de Ukko parece constituir um tema estrutural análogo às relações do tietäjä para com esse mesmo deus - e cujos auxílios pedidos, inclusive, eram iguais -. Diversos encantamentos registrados no século XIX mostram esses especialistas religiosos finlandeses pedindo pela ajuda do deus nos mesmos moldes que Lemminkäinen o faz:

Ukko, Criador nas alturas, velho homem dos céus, Erga uma cerca de bétula, construa uma cerca de ferro Em volta de minha casa, em ambos os lados do meu povo (SIIKALA, 2002b, p. 204);

Traga, Ukko, um casaco de pele flamejante Uma camisa de fogo, meu Ämma, Deixe-me vesti-las (SIIKALA, 2002b, p. 288).

estabelecida. É por isso que todos os outros deuses e heróis, não importando seu papel na narrativa e nem seus atos mais ou menos divinos, recorrem a Ukko, que assumiu as características de um deus otiosus que, após ter criado todo o resto, só interfere quando é invocado (PENTIKÄINEN, 1999, p. 139; 160).

40 Uma das versões do mito cosmogônico, segundo Lönnrot, seria a de que no começo havia apenas Ukko, que teria criado o ar, que deu surgimento à água e, desta, nasceu IImatar, o Espírito do Ar e primeiro Espírito da Natureza (KAUKONEN, 1990, p. 173). 
Ou, ainda:

Ukko, rei dourado

Homem verdadeiro e capaz,

Anjo supremo do Senhor

O melhor dos servos do Senhor,

Acenda, Ukko, um novo fogo,

Traga nova e fresca neve,

Faça tremer uma das extremidades do lago

Sopre seu chifre no charco

Para que os demônios de Hiisi desaparecessem

Os diabos também temeriam!

Ressoe pelas nuvens do céu

Exploda pelas forjas celestiais

Conforme se aproxima a Hora de Deus

Conforme a ajuda de Deus chega caminhando!

Traga, Ukko, um arco flamejante,

Uma espada relampejante

Com a qual golpearei o cachorro de Tuoni,

Perseguirei o mordedor de ossos! (SIIKALA, 2002b, p. 289).

Assim, conforme o que foi explicitado, notamos que as runosongs coletadas por Elias Lönnrot em pleno século XIX ainda retinham conteúdos reveladores da visão de mundo mitológico-religiosa dos tietäjä. Ainda que passando por processos de textualização e edição, esse conteúdo conseguiu se manifestar e sobreviver na Kalevala, fazendo com que a epopeia da Finlândia fosse, também, um épico tematicamente xamanístico. A identidade do povo finlandês, então, foi consolidada no XIX como sendo, em certa medida, herdeira de um passado mágico e xamânico. Mesmo os cantores do XIX que não eram precisamente da tradição tietäjä e manifestavam o habitus do vocalista mantinham parcialmente essas temáticas em seus cantos, ainda que com menor peso e com outros intuitos - mais performáticos - (SIIKALA, 2002a, p. 38-39) tendo fornecido também a Lönnrot um conteúdo mitológico nas canções perpassado por visões de mundo xamânicas.

\section{Considerações finais}

Ao término de nossa exposição, ressaltamos uma vez mais - talvez agora com o entendimento melhor da parte do leitor - o quanto a Kalevala mostra-se uma obra fluida que dificilmente poderá ser entendida se abordada apenas de um ângulo, segundo um único aspecto. 
Aqueles interessados em analisar de que maneira canções épicas e o mecanismo da oralidade são textualizados e transcritos, passando por questões de interpolações e autoria, podem abordar a Kalevala como o épico de Lönnrot; aqueles que desejam descobrir de que modo o Romantismo utiliza, ressalta e modela conteúdos vernaculares e tradicionais dentro de sua empreita e perspectiva nacionalista podem entendê-la como o épico nacional finlandês; os estudiosos das tradições folclóricas, mitologias e religiões podem buscar quais os símbolos e estruturas oriundos da religião finlandesa pré-cristã que teriam alguma reminiscência na Kalevala, ainda que obviamente negociados de acordo com uma série de agendas específicas (incluindo a noção cristã de Lönnrot), passando pelo modo como a tradição tietäjä manteve tais elementos vivos até o XIX. Estes podem toma-la como um folk epic ou, conforme dissemos, como um tradition-oriented epic (HONKO, 1990a, p. 181; 2000, p. 7). As possibilidades de investigação são inúmeras e pluralidade de perspectivas metodológicas para entender um material como a Kalevala são extremamente necessárias. A única máxima que precisamos manter o tempo todo, que dificilmente pode ser relativizada, é a de que estamos diante de um material literário cujos conteúdos que o antecederam são, por sua vez, pré-literários (KAUKONEN, 1990, p. 164).

Tendo consolidada a sua posição de inegável importância enquanto a epopeia finlandesa, a Kalevala terminou por ser também pioneira num movimento que se estendeu por diversos países do Báltico, igualmente colonizados por séculos a fio: o do uso do folclore e da mitologia vernaculares na criação de grandes épicos que seriam portadores e reveladores da autêntica identidade nativa (vista aos olhos do Romantismo como o Volksgeist de Hegel), em oposição à cultura e símbolos de seus colonizadores. A Kalevala serviu de inspiração direta para o épico dos estonianos, o Kalevipoeg (O Filho de Kalev), idealizado por Friedrich Robert Faehlmann e, no advento de sua morte, finalizado por Friedrich Reinhold Kreutzwald ${ }^{41}$; e também do épico letão Lāčplēsis (O Matador de Urso) por Andrejs Pumpurs. Estamos diante de um fenômeno que conectou todo o Báltico por meio do uso dos épicos como emancipação e consolidação identitária, algo que interessa desde sociólogos e antropólogos aos estudiosos da literatura e religião.

\footnotetext{
${ }^{41}$ Com a tradução para o alemão, a Kalevala tornou-se amplamente lida pelos estonianos, principalmente por Kreutzwald, que não lia em finlandês. Inclusive, Elias Lönnrot se encontrou pessoalmente com Kreutzwald e Faehlmann quando viajou para Võru, no sul da Estônia (LAUGASTE, 1990, p. 269-270).
} 
Esperamos ter elencado alguns dos principais elementos básicos e discussões existentes em torno da Kalevala finlandesa, desejosos de ter fornecido algum impulso e ponto de partida para que a pesquisa brasileira volte seu olhar para essa obra de valor inestimável.

\section{Referências bibliográficas}

ALVES, Victor Hugo Sampaio. Diferentes sons do trovão: uma perspectiva comparativa entre os deuses Thor, Ukko e Horagalles. João Pessoa, 2019. 219 p. Dissertação (Mestrado em Ciências da Religião) - Universidade Federal da Paraíba.

ANÔNIMO. The Nibelungenlied - The Lay of the Nibelungs. Introduction and translation by Cyril Edwards. Oxford: Oxford World's Classics, 2010.

ABONDOLO, Daniel. Introduction. In: ABONDOLO, Daniel [Ed.]. The Uralic Languages. New York: Routledge, 2006, p. 1-43.

DUNDES, Alan. Nationalistic Inferiority Complexes and the Fabrication of Fakelore: A Reconsideration of Ossian, the Kinder und Hausmärchen, the Kalevala and Paul Bunyan. In: Journal of Folklore Research, Indiana: v. 22, n. 1, p. 5-18.

ELIADE, Mircea. Shamanism: Archaic Techniques of Ecstasy. Princeton: University Press, 2004.

FROG. O berserkr escandinavo, o tietäjä fino-careliano e uma história de tecnologias rituais. In: Scandia - Journal of Medieval Norse Studies, João Pessoa: n. 2, p. 232-287, 2019.

FROG. Lemminkäinen's Death in the Labyrinth of History. In: MATTEO, Vesa; FROG [Ed.]. Kalevala: Epic, Magic, Art and Music. Viterbo: Bifröst, 2014, p. 383-413.

HATTO, Arthur Thomas. Traditions of Heroic and Epic Poetry. London: Legenda, 1980.

FROMM, Hans. Kalevala and Nibelungenlied: The Problem of Oral and Written Composition. In: HONKO, Lauri [Ed.]. Religion, Myth and Folklore in the World's Epics: The Kalevala and its Predecessors. Berlin: Mouton de Gruyter, 1990, p. 93-115.

HARVILAHTI, Lauri; RAHIMOVA, Elina. Lemminkäinen: Adventure-Loving Braggart of Mythic Hero?. In: FROG [Ed.]; SIIKALA, Anna-Leena [Ed.]; STEPANOVA, Eila [Ed.]. Mythic Discourses: Studies in Uralic Traditions. Helsinque: Finnish Literature Society, 2012, p. 68-81.

HULTKRANTZ, Åke. A Definition of Shamanism. In: Temenos, Finlândia: n. 9, p. 25-37, 1973. HONKO, Lauri. The Kalevala as Performance. In: HONKO, Lauri [Ed.]. The Kalevala and the World's Traditional Epics. Tampere: Finnish Literature Society, 2002, p. 13-26.

HONKO, Lauri. Text as process and practice: the textualization of oral epics. In: HONKO, Lauri [Ed.]. Textualization of Oral Epics. Berlin: Mouton de Gruyter, 2000, p. 3-56. 
HONKO, Lauri. The Kalevala and the world's epics: an introduction. In: HONKO, Lauri [Ed.]. Religion, Myth and Folklore in the World's Epics: The Kalevala and its Predecessors. Berlin: Mouton de Gruyter, $1990 a, \quad$ p. 1-28. HONKO, Lauri. The Kalevala: The Processual View. In: HONKO, Lauri [Ed.]. Religion, Myth and Folklore in the World's Epics: The Kalevala and its Predecessors. Berlin: Mouton de Gruyter, 1990b, p. 181-230.

HONKO, Lauri. The Kalevala: Problems of Interpretation and Identity. In: HONKO, Lauri [Ed.]. Religion, Myth and Folklore in the World's Epics: The Kalevala and its Predecessors. Berlin: Mouton de Gruyter, 1990c, p. 555-577.

KALLIO, Kati; FROG; SARV, Mari. What to Call the Poetic Form - Kalevala-Meter or Kalevalaic Verse, regivärss, Runosong, the Finnic Tetrameter, Finnic Alliterative Verse or Something Else?. In: The Retrospective Methods Network, Helsinque: n. 12-13, p. 139-161, 2017.

KAUKONEN, Väinö. The Kalevala as Epic. In: HONKO, Lauri [Ed.]. Religion, Myth and Folklore in the World's Epics: The Kalevala and its Predecessors. Berlin: Mouton de Gruyter, 1990, p. 157181.

KUUTMA, Kristin. Collaborative Representations: Interpreting the Creation of a Sámi Ethnograpy and a Seto Epic. Helsinque: Academia Scientiarum Fennica, 2006.

KUUSI, Matti. Epic Cycles as the Basis for the Kalevala. In: HONKO, Lauri [Ed.]. Religion, Myth and Folklore in the World's Epics: The Kalevala and its Predecessors. Berlin: Mouton de Gruyter, 1990, p. 133-156.

LA FUENTE, José Andrés Alonso de. ¿Brujos y magos en el Kalevala?. In : 'Illu Revista de Ciencias de las Religiones, Madrid: n. 11, p. 39-62, 2006.

LAUGASTE, Eduard. The Kalevala and Kalevipoeg. In: HONKO, Lauri [Ed.]. Religion, Myth and Folklore in the World's Epics: The Kalevala and its Predecessors. Berlin: Mouton de Gruyter, 1990, p. 265-286.

LANGER, Johnni. Edda Poética. In: LANGER, Johnni (Org.). Dicionário de Mitologia Nórdica: símbolos, mitos e ritos. São Paulo: Hedra, 2015, p. 146-149.

LIND, John H. Finland. In: MURRAY, Alan V. [Ed.]. The Crusades: An Encyclopedia, V. I. California: ABC CLIO, 2006, p. 436-438.

LÖNNROT, Elias. Kalevala. Tradução de Merja de Mattos-Parreira e Ana Isabel Soares. Lisboa: Dom Quixote, 2013.

LÖNNROT, Elias. Kalevala: Canto Primeiro. Tradução de Álvaro Faleiros e José Bizerril. São Paulo: Ateliê Editorial, 2015.

LÖNNROTH, Lars. The Old Norse Analogue: Eddic Poetry and Fornaldarsaga. In: HONKO, Lauri [Ed.]. Religion, Myth and Folklore in the World's Epics: The Kalevala and its Predecessors. Berlin: Mouton de Gruyter, 1990, p. 73-92. 
MAGALDI, Carolina Alves. Paratextos das traduções brasileiras da Kalevala e do Popol Vuh ao longo do espaço e tempo. Juiz de Fora, 2013. 262 p. Tese (Doutorado em Letras/Estudos Literários) - Universidade Federal de Juiz de Fora.

MAGALDI, Carolina Alves. O mito e o mito da Kalevala. In: Darandina, Juiz de Fora: n. 12, s.p., 2010.

MAGALDI, Carolina Alves. Kalevala: a utopia da narrativa primordial. In: Fronteiraz, São Paulo: $\mathrm{n}$. 4, p. 1-9, 2009.

MAGALDI, Carolina Alves. Kalevala: literatura, história e formação nacional. Juiz de Fora, 2006. 104 p. Dissertação (Mestrado em Letras/Teoria da Literatura) - Universidade Federal de Juiz de Fora.

NÓBREGA, Marcos Saulo de Assis. Uns versos do povo, uns cantos da nossa gente: breves considerações sobre a Kalevala nas composições de Jean Sibelius. In: Notícias Asgardianas, João Pessoa: n. 11, p. 34-46, 2016.

OINAS, Felix. Russian and Finnish Epic Songs. In: HONKO, Lauri [Ed.]. Religion, Myth and Folklore in the World's Epics: The Kalevala and its Predecessors. Berlin: Mouton de Gruyter, 1990, p. 287311.

OINAS, Felix. The Balto-Finnic Epics. In: OINAS, Felix [Ed]. Heroic Epic and Saga: An Introduction to the World's Great Folk Epics. Indiana: University Press, 1978, p. 286-310.

PENTIKÄINEN, Juha. Kalevala Mythology: Expanded Edition. Indiana: Indiana University Press, 1999.

SARMELA, Matti. Finnish Folklore Atlas. Helsinque: Matti Sarmela Independent Publishing, 2009.

SARV, Mari. Regional Variation in Folkloric Meter: The Case of Estonian Runosong. In: The Retrospective Methods Network, Helsinque: n. 15, v.1, p. 6-17, 2015.

SIIKALA, Anna-Leena. The singer ideal and the enrichment of poetic culture: why did the ingredients for the Kalevala come from Viena Karelia? In: HONKO, Lauri [Ed.]. The Kalevala and the World's Traditional Epics. Tampere: Finnish Literature Society, 2002a, p. 26-44.

SIIKALA, Anna-Leena. Mythic Images and Shamanism: A Perspective on Kalevala Poetry. Helsinque: Academia Scientiarum Fennica, 2002b.

SIIKALA, Anna-Leena. Body, Performance, and Agency in Kalevala Rune-Singing. In: Oral

Tradition, Harvard: n. 15, v. 2, p. 255-278, 2000.

SIIKALA, Anna-Leena. Singing of Incantations in Nordic Tradition. In: Scripta Instituti Donneriani Aboensis, Finlândia: n. 13, p. 191-205, 1990.

TOLLEY, Clive. The Kalevala as a model for our understanding of the composition of the Codex Regius of the Poetic Edda. In: Turun yliopiston folkloristikan julaisuja, Helsinque: n. 3, v. 1, p. 114-143, 2013. 
VOIGT, Vilmos. The Kalevala and the Epic Traditions of Europe. In: HONKO, Lauri [Ed.]. Religion, Myth and Folklore in the World's Epics: The Kalevala and its Predecessors. Berlin: Mouton de Gruyter, 1990, p. 247-265.

WILSON, William. Folklore and Nationalism in Modern Finland. Bloomington \& London: Indiana University Press, 1976. 